\title{
Influence of early feeding with different diet composition on performance and intestinal morphology of layer-type chicks during the brooding period
}

\author{
M.K. Abou-Elnaga ${ }^{1}$ and S. Selim ${ }^{2,3}$ \\ Menoufia University \\ ${ }^{1}$ Faculty of Agriculture, Department of Poultry Production, ${ }^{2}$ Faculty of Veterinary Medicine, Department of Nutrition and Clinical \\ Nutrition, P.O. Box 32514, Shibin El-Kom, Egypt
}

KEY WORDS: early feeding, fasting, performance, gastrointestinal tract, histology, chicks

Received: 8 January 2018

Revised: 20 April 2018

Accepted: 27 August 2018

${ }^{3}$ Corresponding author:

e-mail: shimaaselim@vet.menofia.edu.eg

\begin{abstract}
The study was conducted to examine the effects of early feeding with diets of different composition or fasting for $72 \mathrm{~h}$ on performance, intestinal organs development and intestinal histomorphology of layer-type chicks during the brooding period. In total, 400 chicks (50\% males, $50 \%$ females) were randomly allocated to 4 treatments with 4 replications of 25 chicks each. The dietary treatments during the first $72 \mathrm{~h}$ of life were: $\mathrm{T1}$ (control) - fasting, T2 - a starter layer diet containing crude protein (CP) $20 \%$ and metabolizable energy (ME) $11.84 \mathrm{MJ} / \mathrm{kg}, \mathrm{T} 3$ - a diet containing $20 \% \mathrm{CP}$ and $11.81 \mathrm{MJ} / \mathrm{kg}$ ME ( $3 \%$ molasses in its composition), and T4 - a starter broiler diet $(23 \%$ $\mathrm{CP}$ and $12.68 \mathrm{MJ} / \mathrm{kg} \mathrm{ME}$ ). For the whole 42-day experimental period, it was indicated that birds fed $\mathrm{T} 4$ and $\mathrm{T} 3$ diets had higher body weight gain and better feed conversion ratio than fasted ones. Chicks fed T4 diet had the highest intestinal weight and length at day 14 of age. Whereas, birds from T3 group had increased gizzard weight than other groups both at days 14 and 28 of age. At day 14 of age, increased duodenal villus height and width and smaller crypt depth were recorded in T4 group in comparison to fasted and other groups of animals. Longer villi and smaller crypt depth of jejunum were found in $\mathrm{T} 4$ and T3 chicks than in fasted ones. Longer ileal villi was observed in T4 birds at day 14 of age. The obtained results suggest that early feeding with a diet rich in $\mathrm{CP}$ or containing molasses addition has beneficial effects on the production performance and intestinal development of layer-type chicks.
\end{abstract}

\section{Introduction}

In the current poultry industry, birds often do not have free access to feed and water during the first 48-72 $\mathrm{h}$ post-hatch due to differences in the time of hatching and management practices. Delayed access to feed and water post-hatch has been reported to negatively influence yolk utilization, survivability, gastrointestinal development, carcass yield and im- munological development (e.g., Yang et al., 2009; Pretorius, 2011; Shinde et al., 2015; Sarlak et al., 2016). Saki (2005) reported a linear relationship between the weight of the first week of rearing and the slaughter weight in broiler chickens. Therefore, early feeding of post-hatch chicks could greatly influence the growth performance of broiler chickens (Yang et al., 2009). Birds that have early access to a high amino acid diet, even in the presence of sub- 
clinical necrotic enteritis, were shown to have better performance and immune response (Keerqin et al., 2017).

The yolk sac of the hatching chicks is a good source of fat and protein, but it has low carbohydrates content (Uni and Ferket, 2004). Investigation of chicks close to hatch indicates that yolk during the first $48 \mathrm{~h}$ post-hatch contributes to the development of the small intestine (Noy and Sklan, 1999). Newly hatchlings are less efficient in utilizing nutrients, and diets containing easily digestible nutrients can be beneficial for them (Pretorius, 2011). Inclusion of highly digestible raw materials in the pre-starter diets, such as soy protein, glucose-based products and simple sugars, was shown to have positive impacts on the production performance of broiler chickens (Batal and Parsons, 2004; Longo et al., 2005). Recently, Sarlak et al. (2016) observed that feeding a maize-soybean meal $(2850 \mathrm{kcal} / \mathrm{kg} \mathrm{ME}$ and $22.73 \% \mathrm{CP}$ ) as a starter diet for newly hatched chicks has a beneficial effect on their performance, immune status and morphological development of the intestine.

Suitable diet composition and optimal feed formulation specified during the first $72 \mathrm{~h}$ of layer-type chicks life are limited. Inclusion of highly digestible proteins and carbohydrates in the pre-starter diet could be used as an investment in poultry production to minimize the need for gluconeogenesis in order to maintain body reserves. Therefore, the current study was designed to investigate the effects of early feeding with different diet composition and fasting during the first $72 \mathrm{~h}$ of post-hatching on growth performance, and intestinal development and histomorphology of layer-type chicks during the brooding period.

\section{Material and methods}

\section{Hatching eggs, chicks and housing}

All the procedures used in the current study have been approved by the Ethical Commitee of Faculty of Agriculture, Menoufia University (Egypt). Eggs from Norfa laying breeder flock (crossing of exotic and local egg breeds, White Leghorn $\times$ Fayoumi $\times$ White Baladi (Kolstad and Abdou, 2000) at the age of 72 weeks) weighing between 40 and $45 \mathrm{~g}$ were taken and set for incubation at an egg shell temperature of $37.8{ }^{\circ} \mathrm{C}$ and relative humidity about $50 \%$ in a commercial hatchery (Poultry Research Farm, Faculty of Agriculture, Menoufia University, Egypt). On day 18 of the incubation period, eggs were transferred to the hatchery. Hatching trays were checked every $4 \mathrm{~h}$, and chicks that had hatched were weighed and wing-banded, and the hatching time was reported. A group of 400 hatched chicks (50\% males, 50\% females) was used as experimental birds. Hatching trays were divided with partitions and 4 different treatments were carried out. All chicks were transferred from the hatchery after $72 \mathrm{~h}$ post-hatching and placed in the floor pens, bedded with clean wood shavings. The light regimen was continuous during the first week and then decreased to $23 \mathrm{~h}$ of light thereafter. Room temperature was kept at $33{ }^{\circ} \mathrm{C}$ for the first week and $30{ }^{\circ} \mathrm{C}$ for the second week, which was further gradually reduced to $22{ }^{\circ} \mathrm{C}$ till the end of the experiment. All experimental chicks were reared under the same standard management practices and routine vaccination.

\section{Experimental diets}

A completely randomized design with 4 treatments and 4 replications per treatment with 25 birds per replicate was used in the study. Four dietary treatments: T1 (control) - fasting, T2 - a starter layer diet containing crude protein (CP) 20\% and metabolizable energy (ME) $11.84 \mathrm{MJ} / \mathrm{kg}$, T3 - a diet containing 20\% CP and $11.81 \mathrm{MJ} / \mathrm{kg} \mathrm{ME}$ (3\% molasses in its composition), and T4 - a starter broiler diet $(23 \% \mathrm{CP}$ and $12.68 \mathrm{MJ} / \mathrm{kg} \mathrm{ME}$ were considered during the first $72 \mathrm{~h}$ of chicks life. All chicks $72 \mathrm{~h}$ immediately post-hatching (after fasting or feeding experimental diets) were fed layer starter mash diet $(20 \% \mathrm{CP}$ and $11.84 \mathrm{MJ} / \mathrm{kg} \mathrm{ME}$, T2) ad libitum for a period of 42 days post-hatch. The recommendation tables of National Research Council (NRC, 1994) for the nutrient requirements of white-egg breeders were utilized to calculate the nutrient requirements for Norfa layer chicks (AbdEl Rahman and Attia, 2001; Zanaty, 2006). The composition of the experimental diet was based on NRC (1994) tabulated values for feedstuffs. The compositions, nutrient concentrations and the proximate chemical analysis, namely dry matter (DM), $\mathrm{CP}$, ether extract (EE) as well as crude fibre (CF) and ash (AOAC International, 2005) of the diets are presented in Table 1.

\section{Sampling, measurements and methods of analysis}

Body weights of birds were determined at days $1,14,28$ and 42 of age. Feed intake and weight gain were recorded in the different experimental periods and feed conversion ratio (feed intake/weight gain) was calculated accordingly. Mortality was recorded when it occurred. At days 14 and 28 of age, 
Table 1. Ingredients and nutrient composition of different early diet composition during the first $72 \mathrm{~h}$ of post-hatching

\begin{tabular}{|c|c|c|c|}
\hline \multirow{2}{*}{ Indices } & \multicolumn{3}{|c|}{ Early feeding dietary treatments ${ }^{1}$} \\
\hline & $\mathrm{T} 2$ & T3 & T4 \\
\hline \multicolumn{4}{|l|}{ Ingredients } \\
\hline ground yellow maize & 62.00 & 61.60 & 49.00 \\
\hline soybean meal (44\% CP) & 33.80 & 31.30 & 42.90 \\
\hline vegetable oils & - & - & 4.90 \\
\hline limestone, ground & 1.70 & 1.60 & 1.50 \\
\hline mono-calcium phosphate & 1.70 & 1.70 & 1.10 \\
\hline vitamin and mineral mixture ${ }^{2}$ & 0.30 & 0.30 & 0.30 \\
\hline salt (sodium chloride) & 0.30 & 0.30 & 0.30 \\
\hline DL-methionine ${ }^{3}$ & 0.20 & 0.20 & \\
\hline molasses & & 3.00 & \\
\hline \multicolumn{4}{|c|}{ Calculated energy and nutrient content ${ }^{4}$} \\
\hline $\mathrm{CP}, \mathrm{g} / \mathrm{kg}$ & 201.4 & 201.5 & 230.0 \\
\hline ME, MJ/kg diet & 11.84 & 11.81 & 12.68 \\
\hline ME:CP, kcal/g & 140 & 140 & 132 \\
\hline $\mathrm{EE}, \mathrm{g} / \mathrm{kg}$ & 37.3 & 38.7 & 40.8 \\
\hline $\mathrm{CF}, \mathrm{g} / \mathrm{kg}$ & 26.3 & 26.7 & 22.0 \\
\hline calcium, g/kg & 10.30 & 10.30 & 8.70 \\
\hline available phosphorus, g/kg & 4.70 & 4.70 & 3.50 \\
\hline lysine, g/kg & 10.40 & 10.40 & 13.50 \\
\hline methionine, $\mathrm{g} / \mathrm{kg}$ & 5.30 & 5.30 & 3.60 \\
\hline \multicolumn{4}{|l|}{ Chemical analysis ${ }^{5}, \mathrm{~g} / \mathrm{kg}$} \\
\hline DM & 922 & 925 & 926 \\
\hline $\mathrm{CP}$ & 199 & 200 & 228 \\
\hline EE & 36.8 & 38.0 & 39.8 \\
\hline CF & 25.4 & 25.6 & 21.4 \\
\hline ash & 50.0 & 48.1 & 47.5 \\
\hline
\end{tabular}

${ }^{1} \mathrm{~T} 1$ - control, no feed or water were give during the first $72 \mathrm{~h}$ of posthatching, all chicks after $72 \mathrm{~h}$ post-hatch were fed layer starter mash diet (the diet T2) ad libitum for a period of 42 days; ${ }^{2}$ supplied per $\mathrm{kg}$ of diet: IU: vit. A 12,000, vit. D3 3,000; mg: vit. E 40, vit. K3 3, vit. B1 2, vit. B2 6, vit. B6 5, vit. B12 0.02, niacin 45, biotin 0.075, folic acid 2 , pantothenic acid 12, Mg 100, Zn 600, Fe 30, Cu 10, I 1, Se 0.2, Co 0.1; ${ }^{3}$ DL-Methionine, Met AMINO ${ }^{\circledR}$ (DL-2-amino-4-(methyl-thio)-butane acid by Feed Grade 99\% (Evonik Nutrition \& Care GmbH, Germany); ${ }^{4}$ the composition of the experimental diets was based on NRC (1994) tabulated values for feedstuffs, ME:CP - metabolizable energy:crude protein ratio; ${ }^{5}$ The proximate chemical analysis of dry matter (DM), crude protein $(C P)$, ether extract $(E E)$, crude fibre $(C F)$ and ash was performed according to AOAC International (2005)

two chicks per replicate, close to the average group mean weight, were selected, weighted and sacrificed by cervical dislocation. The gastrointestinal tract from the proventriculus to the end of the intestine was excised. The small intestine (after removal of digesta), empty gizzard and liver were weighted and expressed as a percentage of live body weight. The length of small intestine was recorded and expressed as a function of body weight. For histomorphological analyses, segments of approximately $2 \mathrm{~cm}$ were excised from duodenum, jejunum, and ileum at days 14 and 28 of age. Segments referred to the midpoint of the duodenum (from gizzard to pancreo-biliary duct), jejunum (the midpoint between the entry of the common bile duct and the Meckel's diverticulum) and ileum (from the Meckel's diverticulum to ileocecal junction). Particular segments were gently flushed and rinsed with $0.9 \%$ physiological saline and then fixed in 4\% neutral-buffered formalin solution for histological study.

Samples of the small intestine were transferred from formaldehyde after dehydration through passing tissue by sequences of alcohol solutions, and then were cleared by xylene and embedded in paraffin. All samples were sectioned at $5-\mu \mathrm{m}$ thickness by using a rotary microtome. Sections were sequentially transferred to glass slides and stained with hematoxylin and eosin. After glass slides being dried, sections were examined using a light microscope. Morphometric measurements were performed on the selected 9 villi from each sample. The height of intestinal villi was measured from the tip to the base of villi at the opening crypt, and the villus width was measured at its midpoint (Geyra et al., 2001). The intestinal crypt depth was measured from the base of the villi to submucosa, and the muscular thickness from the submucosa to the external layer of the intestine (Geyra et al., 2001).

\section{Statistical analysis}

Experimental data were subjected to the analysis of variance (ANOVA) using IBM SPSS Statistics 22 statistical package (SPSS Inc., Chicago, IL, USA) as a completely randomized design. Significant differences among the treatments were determined using Tukey's test at $P<0.05$.

\section{Results}

\section{Growth performance}

The body weights of layer chicks were different during the whole experimental period as a result of fasting and compositions of different early diets (Table 2). Birds offered diets with different compositions had significantly $(P<0.05)$ higher body weight $72 \mathrm{~h}$ after hatch, at weeks 2 (except T2 group), 4 (except T2 and T3 groups) and 6 (except T2 group) of age in comparison to those deprived of feed and water (T1). Data revealed that at week 6 of age birds fed T4, and those fed T3 diets had higher $(P=0.04)$ body weight than those fed starter layer diet (T2) or fasted for the first $72 \mathrm{~h}$ post-hatching. Chicks fed T4 and T3 diets during $72 \mathrm{~h}$ post-hatch had also significantly higher body weight gain $(P=0.03)$ in comparison to control (T1) and T2 groups during the whole period from hatch to day 42 of life. 
Table 2. Effect of early feeding with diets of different composition on the production performance of chicks during the brooding period

\begin{tabular}{|c|c|c|c|c|c|c|}
\hline \multirow{2}{*}{ Parameters } & \multicolumn{4}{|c|}{ Early feeding treatments ${ }^{1}$} & \multirow{2}{*}{\multicolumn{2}{|c|}{ SEM ${ }^{2} P$-value }} \\
\hline & $\mathrm{T} 1$ & T2 & 3 & & & \\
\hline \multicolumn{7}{|l|}{ Body weight, $\mathrm{g}$} \\
\hline $\begin{array}{l}\text { after } 72 \mathrm{~h} \text { post- } \\
\text { hatch }\end{array}$ & $31.0^{\mathrm{b}}$ & $33.2^{\mathrm{a}}$ & $33.5^{\mathrm{a}}$ & $34.0^{\mathrm{a}}$ & 0.31 & 0.03 \\
\hline day 14 & $80.5^{b}$ & $83.8^{\mathrm{ab}}$ & $85.9^{\mathrm{a}}$ & $86.6^{\mathrm{a}}$ & 1.32 & 0.01 \\
\hline day 28 & $147^{\mathrm{b}}$ & $153^{\mathrm{ab}}$ & $155^{a b}$ & $163^{a}$ & 4.01 & 0.02 \\
\hline day 42 & $256^{\mathrm{b}}$ & $267^{\mathrm{b}}$ & $283^{a}$ & $291^{\mathrm{a}}$ & 6.07 & 0.04 \\
\hline \multicolumn{7}{|l|}{ Body weight gain, $g$} \\
\hline hatch-14 days & $49.5^{b}$ & $50.6^{\mathrm{ab}}$ & $52.4^{a}$ & $52.6^{\mathrm{a}}$ & 1.32 & 0.03 \\
\hline $14-28$ days & $66.4^{b}$ & $69.2^{\mathrm{ab}}$ & $69.5^{\mathrm{ab}}$ & $76.4^{a}$ & 4.6 & 0.01 \\
\hline 28-42 days & $110^{b}$ & $114^{\mathrm{ab}}$ & $127^{\mathrm{a}}$ & $128^{a}$ & 7.2 & 0.02 \\
\hline hatch-42 days & $225^{b}$ & $234^{\mathrm{ab}}$ & $249^{a}$ & $257^{\mathrm{a}}$ & 10.1 & 0.03 \\
\hline \multicolumn{7}{|c|}{ Feed intake, g/chick } \\
\hline hatch-14 days & $151^{\mathrm{a}}$ & $150^{\mathrm{a}}$ & $145^{\mathrm{ab}}$ & $136^{b}$ & 4.4 & 0.03 \\
\hline $14-28$ days & $231^{a}$ & $226^{a}$ & $221^{a}$ & $205^{b}$ & 4.2 & 0.005 \\
\hline $28-42$ days & $422^{\mathrm{a}}$ & $413^{a}$ & $387^{b}$ & $367^{\circ}$ & 6.3 & 0.001 \\
\hline hatch-42 days & $804^{a}$ & $789^{a}$ & $753^{b}$ & $708^{c}$ & 10.5 & 0.001 \\
\hline \multicolumn{7}{|c|}{ Feed conversion ratio } \\
\hline hatch-14 days & $3.05^{\mathrm{a}}$ & $2.98^{\mathrm{ab}}$ & $2.75^{b c}$ & $2.59^{c}$ & 0.086 & 0.002 \\
\hline $14-28$ days & $3.49^{\mathrm{a}}$ & $3.27^{\mathrm{b}}$ & $3.18^{b}$ & $2.68^{c}$ & 0.059 & 0.005 \\
\hline 28-42 days & $3.84^{a}$ & $3.62^{b}$ & $3.05^{c}$ & $2.87^{d}$ & 0.053 & 0.001 \\
\hline hatch-42 days & $3.57^{\mathrm{a}}$ & $3.37^{b}$ & $3.02^{c}$ & $2.75^{d}$ & 0.044 & 0.001 \\
\hline
\end{tabular}

${ }^{1} \mathrm{~T} 1$ - control, no feed or water during the first $72 \mathrm{~h}$ of post-hatching, T2 - feeding a commercial starter diet containing $20 \%$ crude protein (CP) and $11.84 \mathrm{MJ} / \mathrm{kg}, \mathrm{T} 3$ - feeding a commercial starter diet containing 20\% CP and $11.81 \mathrm{MJ} / \mathrm{kg}$ (diet contained $3 \%$ molasses) and T4 - feeding a commercial starter diet containing 23\% CP and $12.68 \mathrm{MJ} / \mathrm{kg} ;{ }^{2} \mathrm{SEM}$ - pooled standard error of the means; ${ }^{\text {ab }}$ - values in the same row with different superscripts are significantly different at $P<0.05$

Feed intake during the entire experimental period was significantly $(P<0.001)$ influenced by the composition of early diet (level of protein and energy density). Chicks offered T3 treatment were characterized by significantly higher feed intake $(P<0.05)$ than those fed T4 and T2 diets during the first $72 \mathrm{~h}$ of life (5.73 vs 4.98 and $4.90 \mathrm{~g} / \mathrm{d} \pm 0.12$, respectively). Chicks fed T4 diet, followed by those fed T3 showed lower feed intake $(P=0.001)$ than those fed T2 diet and fasted ones (T1) during the entire experimental period from the hatch to day 42 (Table 2). Early feeding during the first $72 \mathrm{~h}$ of life (T4, followed by T3 and T2) was shown to significantly improve FCR of chicks during days $0-14(P=0.002), 15-28$ $(P=0.001)$ and $29-42(P=0.001)$ as compared to fasting ones.

\section{Post-hatch intestinal organ development}

Data of post-hatch intestinal organ development, such as the small intestine weight and length, and liver and gizzard weights at days 14 and 28 of age are presented in Table 3. Intestinal weight $(P=0.004)$ and length $(P=0.001)$ were significantly higher in the T4 group than in fasted and other treatment groups at day 14 of age. Whereas, T2 and T3 chicks had lower intestinal relative weight and length $(P<0.05)$ in comparison to the control group (T1) at day 28 of age. The relative weight of gizzard was significantly higher in T3 chicks than in the other animals at days $14(P=0.002)$ and $28(P<0.05)$ of age. Chicks fed T4 diet immediately after hatch had higher relative weight of the liver $(P<0.05)$ at day 14 of age than those from fasted and T2 groups. There was no significant difference in the relative weight of the liver at day 28 of life among the groups.

Table 3. Effect of early feeding with diets of different composition on the intestinal weight, intestinal length and weight of digestive organs of chicks during the brooding period, $\%$ of live BW

\begin{tabular}{|c|c|c|c|c|c|c|}
\hline \multirow{2}{*}{ Indices } & \multicolumn{4}{|c|}{ Early feeding treatments ${ }^{1}$} & \multirow{2}{*}{ SEM ${ }^{2}$} & \multirow{2}{*}{$P$-value } \\
\hline & $\mathrm{T} 1$ & T2 & T3 & T4 & & \\
\hline \multicolumn{7}{|l|}{ At day 14 of age } \\
\hline intestinal weight & $6.95^{b}$ & $7.39^{b}$ & $7.24^{b}$ & $9.25^{a}$ & 0.293 & $3 \quad 0.004$ \\
\hline intestinal length & $89.5^{b}$ & $81.5^{c}$ & $86.5^{b c}$ & $99.0^{\mathrm{a}}$ & 2.46 & 60.001 \\
\hline gizzard weight & $9.07^{b}$ & $9.13^{\mathrm{ab}}$ & $10.03^{a}$ & $8.29^{b}$ & 0.286 & 60.002 \\
\hline liver weight & $3.17^{c}$ & $3.33^{\mathrm{bc}}$ & $3.54^{\mathrm{ab}}$ & $3.62^{\mathrm{a}}$ & 0.076 & $6 \quad 0.01$ \\
\hline \multicolumn{7}{|l|}{ At day 28 of age } \\
\hline intestinal weight & $11.30^{\mathrm{a}}$ & $9.06^{b}$ & $8.91^{\mathrm{b}}$ & $10.80^{\mathrm{a}}$ & 0.43 & 30.001 \\
\hline intestinal length & $87.5^{\mathrm{a}}$ & $74.5^{b}$ & $77.0^{\mathrm{b}}$ & $83.0^{\mathrm{a}}$ & 3.04 & 0.01 \\
\hline gizzard weight & $8.10^{\mathrm{b}}$ & $8.09^{b}$ & $9.30^{\mathrm{a}}$ & $7.92^{b}$ & 0.347 & 0.02 \\
\hline liver weight & 2.99 & 3.14 & 3.16 & 3.19 & 0.079 & $9 \quad 0.13$ \\
\hline
\end{tabular}

1,2 - see Table 2;. ab - values in the same row with different superscripts are significantly different at $P<0.05$

\section{Intestinal development and morphology}

The average villus height, villus width, crypt depth and muscular thickness of duodenum, jejunum and ileum of birds measured at days 14 and 28 of age are presented in Table 4 . In the duodenum, birds fed T4 diet for $72 \mathrm{~h}$ after hatching had significantly higher villus height and smaller crypt depth $(P<0.001)$ at day 14 of age than those fasted or fed T2 and T3 diets post-hatch. However, there was no significant difference in villus height of the duodenum at day 28 of age between the controlfasted and other treatment groups. The highest villus width of the duodenum in relation to other groups $(P=0.002)$ was observed at day 14 of age in chicks fed T4 diet after hatching compared to fasted and $\mathrm{T} 2$ ones. While, there was no difference in duodenal villus width between fasted and $\mathrm{T} 2$ birds or between T3 and T4 birds. At day 28 of age, birds from T2 group had narrower duodenal villus width $(P=0.001)$ than other treatments. Smaller duodenal 
Table 4. Effect of early feeding with diets of different composition on the intestinal morphology of chicks during the brooding period, $\mu \mathrm{m}$

\begin{tabular}{|c|c|c|c|c|c|c|}
\hline \multirow{2}{*}{ Indices, $\mu \mathrm{m}$} & \multicolumn{4}{|c|}{ Early feeding treatments ${ }^{1}$} & \multirow{2}{*}{ SEM $^{2}$} & \multirow{2}{*}{$P$-value } \\
\hline & $\mathrm{T1}$ & $\mathrm{T} 2$ & T3 & T4 & & \\
\hline \multicolumn{7}{|l|}{ At day 14 of age } \\
\hline \multicolumn{7}{|l|}{ Duodenum } \\
\hline villi height & $1105^{c}$ & $1134^{\mathrm{bc}}$ & $1229^{b}$ & $1353^{\mathrm{a}}$ & 32.9 & $<0.001$ \\
\hline villi width & $127^{\circ}$ & $170^{\mathrm{bc}}$ & $202^{\mathrm{ab}}$ & $250^{a}$ & 17.2 & 0.002 \\
\hline crypt depth & $252^{a}$ & $272^{\mathrm{a}}$ & $244^{\mathrm{a}}$ & $145^{b}$ & 15.7 & 0.001 \\
\hline muscular thickness & $150^{b}$ & $216^{a}$ & $244^{a}$ & $250^{a}$ & 17.6 & 0.002 \\
\hline \multicolumn{7}{|l|}{ Jejunum } \\
\hline villi height & $737^{\circ}$ & $942^{b}$ & $1038^{a}$ & $1093^{a}$ & 24.5 & $<0.001$ \\
\hline villi width & $175^{b}$ & $253^{a}$ & $263^{a}$ & $285^{a}$ & 12.3 & 0.001 \\
\hline crypt depth & $276^{a}$ & $294^{\mathrm{a}}$ & $205^{b}$ & $177^{b}$ & 16.9 & $<0.001$ \\
\hline muscular thickness & 169 & 160 & 191 & 179 & 11.8 & 0.13 \\
\hline \multicolumn{7}{|l|}{ Ileum } \\
\hline villi height & $537^{\circ}$ & $738^{b}$ & $742^{b}$ & $893^{a}$ & 32.7 & 0.004 \\
\hline villi width & 185 & 165 & 153 & 163 & 15.5 & 0.29 \\
\hline crypt depth & 193 & 204 & 215 & 216 & 18.5 & 0.58 \\
\hline muscular thickness & 164 & 175 & 186 & 174 & 8.4 & 0.15 \\
\hline \multicolumn{7}{|l|}{ At day 28 of age } \\
\hline \multicolumn{7}{|l|}{ Duodenum } \\
\hline villi height & 1680 & 1613 & 1591 & 1611 & 32.7 & 0.11 \\
\hline villi width & $275^{a}$ & $129^{b}$ & $229^{a}$ & $258^{\mathrm{a}}$ & 20.4 & 0.001 \\
\hline crypt depth & $272^{a}$ & $255^{\mathrm{ab}}$ & $240^{\mathrm{ab}}$ & $218^{b}$ & 14.7 & 0.03 \\
\hline muscular thickness & 262 & 240 & 256 & 266 & 10.0 & 0.12 \\
\hline \multicolumn{7}{|l|}{ Jejunum } \\
\hline villi height & 1304 & 1336 & 1340 & 1363 & 30.1 & 0.34 \\
\hline villi width & 252 & 232 & 255 & 214 & 14.8 & 0.08 \\
\hline crypt depth & 220 & 198 & 223 & 199 & 10.7 & 0.09 \\
\hline muscular thickness & $285^{a}$ & $261^{\mathrm{ab}}$ & $240^{b}$ & $251^{b}$ & 9.4 & 0.008 \\
\hline \multicolumn{7}{|l|}{ Ileum } \\
\hline villi height & 894 & 936 & 904 & 963 & 27.3 & 0.11 \\
\hline villi width & 248 & 229 & 251 & 220 & 16.9 & 0.28 \\
\hline crypt depth & 209 & 200 & 171 & 190 & 12.2 & 0.07 \\
\hline muscular thickness & 262 & 258 & 237 & 248 & 12.5 & 0.26 \\
\hline
\end{tabular}

1,2 - see Table 2;. ${ }^{\text {ab }}$ - values in the same row with different superscripts are significantly different at $P<0.05$

crypt depth $(P=0.03)$ was shown in T4 chicks at this time point in comparison to the other groups. Feed deprived chicks had significantly smaller duodenal muscular thickness $(P=0.002)$ than early fed birds at day 14 of age. While, muscular thickness of the duodenum was not different among treatments at day 28 after hatching.

Jejunal villus height at day 14 of age was significantly higher $(P<0.001)$ in chicks fed T4 diet, followed by T3 and T2 as compared to fasted chicks, while there was no significant difference in the villus height at day 28 of age between the groups. Crypt depth of jejunum was lower $(P<0.001)$ in T3 and T4 birds at day 14 of age than in fasted and T2 birds. No significant difference in jejunal muscular thickness was recorded between the experimental groups at day14 post-hatch, while jejunal muscular thickness was greater $(P=0.008)$ in fasted chicks at day 28 of age than T3 and T4 birds. At day 14 of age, the highest villus height of ileum $(P<0.01)$ was observed in T4, followed by T3 and T2 groups in comparison to the feed deprived group. However, there were no significant differences in ileal villus width, crypt depth and muscular thickness among treatments at days 14 or 28 after hatching.

\section{Discussion}

Early access to different forms of feed, either liquid or solid, has been reported to enhance the growth performance of birds in comparison to those with delayed access to feed (Batal and Parsons, 2004; Longo et al., 2005; Saki, 2005; Yang et al., 2009). Under commercial conditions, the absence of feed within the hatchery for 24-48 h has been reported to induce a linear reduction in poultry body weight at $0.17 \mathrm{~g} / \mathrm{h}$ (Sklan et al., 2000). This loss in body weight posthatch is mainly attributed to the metabolic changes, yolk consumption and dehydration occurring in the hatchery during the holding period.

In the present study, the lower body weights of fasted chicks after the holding time (72-h posthatch) and at the end of the experiment (day 42 of age) were in agreement with previous studies (Abed et al., 2011; Sarica et al., 2014; Sarlak et al., 2016) which reported that feed deprivation during the first $48 \mathrm{~h}$ after hatching had adverse effects on the growth performance of broilers. Decreased body weights of fasted chicks could be mainly attributed to a decrease in feed intake and FCR (Abed et al., 2011; Shinde et al., 2015; Sarlak et al., 2016). However, in the present study the lower feed intake, greater body weight gain and better FCR during 0-42 days of age were observed in birds fed T4, followed by those fed T3 and T2 diets for 72-h post-hatch. The results of the current study suggest that feed and water deprivation during the initial $72 \mathrm{~h}$ of life has adverse effect on body weight gain, which could be contributed to a decrease in FCR rather than feed consumption. Other researchers (e.g., Gonzales et al., 2003; Tabedian et al., 2010) reported lower feed intake and higher FCR at days 21 and 42 of age in broilers deprived of feed and water for 24- or 48-h post-hatch. On the other hand, Abed et al. (2011) observed a lower feed intake and FCR in broilers deprived of feed and water for 48-h post-hatch in comparison to control at day 11 of age. The reason for this inconsistency between the studies is unclear. 
Inclusion of 3\% molasses into diet during early feeding resulted in an increase in body weight gain and better FCR than in animals that were feeddeprived. Our findings are consistent with the results of other researchers (Batal and Parsons, 2004; Longo et al., 2005), who stated that the inclusion of sugars in the pre-starter diet led to a significant increase in broiler performance. Recently, Sarlak et al. (2016) observed that birds fed maize gluten-dextrose diet for 5 days after hatching had lower feed intake and body weight gain than those fasted for $24 \mathrm{~h}$ post-hatch or those fed maize-soybean meal diet immediately after hatching. In the study by Sarlak et al. (2016), the lowered feed intake and body weight gain may be attributed to the imbalanced amino acid structure of the used maize gluten meal.

In the present study, the relative intestinal weight and length at day 14 of age was higher in T4 chicks than in fasted and other treatment groups. It was suggested by Sklan and Noy (2003) that chicks might have high protein requirements post-hatching for specific tissues development such as the small intestine (Sklan, 2001). Previous studies (e.g., Mikec et al., 2006; Abed et al., 2011; Sarica et al., 2014) demonstrated that birds deprived of feed post-hatch had lower intestinal weight and length in comparison to those fed typical maize-soybean meal diet. The highest weight and length of the small intestine in the fasted group at day 28 of age in the current study was rather unexpected. Also, Sarlak et al. (2016) observed that the relative weight and length of the small intestine at day 42 of age was higher in broilers fasted for $48 \mathrm{~h}$ post-hatching. It seems that the higher intestinal weight and length in fasted chicks could be an adaptive compensatory mechanism to allow complete recovery of the growth.

The relative weight of gizzard was higher in T3 group in comparison to the other groups at days 14 and 28 of age. These findings are in agreement with those reported by El-Husseiny et al. (2008) who observed that feed deprivation during the first $48 \mathrm{~h}$ posthatch affected intestinal organ development. The current findings suggested that early access to feed rich in CP content or containing molasses stimulates the growth of the small intestine and gizzard. It has been demonstrated that the nutrients found in the yolk were used for intestinal development (Noy and Sklan, 1999). This may clarify why early feeding enhances intestine and gizzard development in comparison to feed deprived chicks. On the contrary, Shinde et al. (2015) and Sarlak et al. (2016) reported that there was no significant difference in the relative weight of gizzard between fasted and early fed birds. The dif- ference between the current study and previous studies could contributed to the different composition of early diet.

Feed deprivation and early feeding with different diet composition affected the structure of the small intestine in layer-type chicks. The histomorphological examination of the small intestine segments at day 14 of age revealed that early feeding a diet containing 23\% CP and $12.68 \mathrm{MJ} / \mathrm{kg} \mathrm{ME}$ (T4) increased duodenal villi height and width, but decreased crypt depth in comparison to treatments (including fasting animals). Furthermore, feed deprived chicks had lower jejunal and ileal villus height and greater jejunal crypt depth in comparison to T3 and T4 groups. The villi height and crypt depth of the absorptive small intestinal epithelium play key roles in the digestion, absorption and assimilation of nutrients (Wang and Peng, 2008). The crypt depth is one of the healthiest and functional histomorphometric parameters of the intestinal status in chicks (Samanya and Yamauch, 2002). Crypt depth can be used as an indicator of the strength and renewal processes of the intestinal epithelium (Samanya and Yamauch, 2002), indicating that larger crypts have rapid tissue turnover and a high demand for new epithelium (Xu et al., 2003). In the current study, decreased crypt depth in T4 group may indicate an efficient tissue turnover and good gut condition (Yegani and Korver, 2008). The adverse effects of feed deprivation immediately posthatching on the small intestine villus height, width and crypt depth were also observed in previous studies (Sarıca et al., 2014; Sarlak et al., 2016). Shorter villi and deeper crypts may lead to reduced nutrient absorption, increased digestive secretion and diarrhea, which in turn diminished growth performance (Yegani and Korver, 2008). Additionally, the tunica muscularis was thicker in the duodenum of early fed birds in comaprison to fasted ones, which may enhance the contact between the mucosa and intestinal content (de Verdal et al., 2010). Therefore, the negative effects of feed deprivation post-hatching on the growth performance of chicks may be correlated with the morphological changes in the development of the small intestine, particularly duodenum and jejunum.

\section{Conclusions}

Feed withdrawal during the first $72 \mathrm{~h}$ immediately after hatching had negative effects on the performance traits of layer-type chicks during the brooding period. Early feeding of a diet containing $23 \%$ of crude protein $(\mathrm{CP})$ and $12.68 \mathrm{MJ} / \mathrm{kg}$ of metabolizable energy (ME) followed by that containing $20 \%$ of CP 
and $11.81 \mathrm{MJ} / \mathrm{kg}$ of ME with 3\% molasses in its nutrient composition improved performance traits in comparison to feed deprivation. The adverse effects of fasting on the growth performance of layertype chicks were correlated with the morphological changes in the small intestine, particularly duodenum and jejunum. The current study suggested that early feeding immediately after hatching has beneficial effects on the growth performance and small intestine development of layer-type chicks during the brooding period. Early feeding vs feed deprivation and their relations with the secretion of digestive enzymes, histological examination of immune organs and the expression of nutrient transporter related genes in layer-type chicks need to be further clarified in future studies.

\section{Acknowledgments}

The authors extend their appreciation to scientific research at the Faculty of Agriculture, University of Menoufia and Histological Laboratory at the Faculty of Veterinary Medicine, University of Sadat City. Authors are thankful to Department of Poultry Production, Faculty of Agriculture, Menoufia University and Department of Nutrition and Clinical Nutrition, Faculty of Veterinary Medicine, Menoufia University for providing the financial support and research facilities.

\section{References}

Abd-El Rahman S.A., Attia Y.A., 2001. Response of Norfa white egg breeders to amino acid supplementations to low protein diets. Arch. Geflugelk. 66, 35-42

Abed F., Karimi A., Sadeghi G., Shivazad M., Dashti S., SadeghiSefidmazgi A., 2011. Do broiler chicks possess enough growth potential to compensate long-term feed and water depravation during the neonatal period? S. Afr. J. Anim. Sci. 41, 33-39, https://doi.org/10.4314/sajas.v41i1.66037

AOAC International, 2005. Official Methods of Analysis of AOAC International. 18 $8^{\text {th }}$ Edition. Gaithersburg, MD (USA)

Batal A.B., Parsons C.M., 2004. Utilization of various carbohydrate sources as affected by age in the chick. Poult. Sci. 83, 1140 1147, https://doi.org/10.1093/ps/83.7.1140

de Verdal H., Mignon-Grasteau S., Jeulin C., Le Bihan-Duval E., Leconte M., Mallet S., Martin C., Narcy A., 2010. Digestive tract measurements and histological adaptation in broiler lines divergently selected for digestive efficiency. Poult. Sci. 89, 1955-1961, https://doi.org/10.3382/ps.2010-813

El-Husseiny O.M., Abou El-Wafa S., El-Komy H.M.A., 2008. Influence of fasting or early feeding on broiler performance. Int. Poult. Sci. 7, 263-271, https://doi.org/10.3923/ijps.2008.263.271

Geyra A., Uni Z., Sklan D., 2001. Enterocyte dynamics and mucosal development in the posthatch chick. Poult. Sci. 80, 776-782, https://doi.org/10.1093/ps/80.6.776
Gonzales E., Kondo N., Saldanha E.S., Loddy M.M., Careghi C., Decuypere E., 2003. Performance and physiological parameters of broiler chickens subjected to fasting on the neonatal period. Poult. Sci. 82, 1250-1256, https://doi. org/10.1093/ps/82.8.1250

Keerqin C., Wu S.-B., Svihus B., Swick R., Morgan N., Choct M., 2017. An early feeding regime and a high-density amino acid diet on growth performance of broilers under subclinical necrotic enteritis challenge. Anim. Nutr. 3, 25-32, https://doi. org/10.1016/j.aninu.2017.01.002

Kolstad N., Abdou F.H., 2000. NORFA: The Norwegian-Egyptian project for improving local breeds of laying hens in Egypt. In: S. Galal, J. Boyazoglu, K. Hammond (Editors). Proceedings of the Workshop on Developing Breeding Strategies for Lower Input Animal Production Environments. Bella (Italy). ICAR Technical Series 3. ICAR, Villa del Ragno, Rome (Italy), pp. 301-306

Longo F.A., Menten J.F.M., Pedroso A.A., Figueiredo A.N., Racanicci A.M.C., Gaiotto J.B., Sorbara J.O.B., 2005. Carbohydrates in the diets of newly hatched chicks. Rev. Bras. Zootec. 34, 123-133, https://doi.org/10.1590/S151635982005000100016

Mikec M., Biđin Z., Valentić A., Savić V., Amšel Zelenika T., RagužĐurić R., Lukaé Novak I., Baleńovic M., 2006. Influence of environmental and nutritional stressors on yolk sac utilization, development of chicken gastrointestinal system and its immune status. Worlds Poult. Sci. J. 62, 31-40, https://doi.org/10.1079/ WPS200582

Noy Y., Sklan D., 1999. Different types of early feeding and performance in chicks and poultry. J. Appl. Poult. Res. 8, 16-24, https://doi. org/10.1093/japr/8.1.16

NRC (National Research Council), 1994. Nutrient Requirements of Poultry: $9^{\text {th }}$ Revised Edition. The National Academies Press. Washington, DC (USA), https://doi.org/10.17226/2114

Pretorius C., 2011. The effect of highly digestible carbohydrate and protein sources included in pre-starter diets of broilers on their performance. MSc Thesis. University of Stellenbosch, Stellenbosch (South Africa)

Saki A.A., 2005. Effect of post-hatch feeding on broiler performance. Int. J. Poult. Sci. 4, 4-6, http://doi.org/10.3923/ijps.2005.4.6

Samanya M., Yamauchi K., 2002. Histological alterations of intestinal villi in chickens fed dried Bacillus subtilis var. natto. Comp. Biochem. Physiol. A. Mol. Integr. Physiol. 133, 95-104, http:// doi.org/10.1016/S1095-6433(02)00121-6

Sarıca Ş., Suiçmez M., Çördük M., Özdemir D., Berberoglu E., 2014. Effects of oregano essential oil supplementation to diets of broiler chicks with delayed feeding after hatching. Morphological development of small intestine segments. Ital. J. Anim. Sci. 13, 3172, https://doi.org/10.4081/ijas.2014.3172

Sarlak S., Tabeidian S.A., Gheisari A., 2016. Effects of time of initiation of feeding after hatching and diet composition on performance, carcass characteristics, digestive tract development and immune responses of broilers. Anim. Prod. Sci. 57, 1692-1701, https://doi.org/10.1071/AN15839

Shinde A.S., Goel A., Mehra M., Rokade J., Bhadauria P., Mandal A.B., Bhanja S.K., 2015. Delayed post hatch feeding affects performance, intestinal morphology and expression pattern of nutrient transporter genes in egg type chickens. J. Nutr. Food Sci. 5, 372, https://doi.org/10.4172/2155-9600.1000372

Sklan D., 2001. Development of the digestive tract of poultry. Worlds Poult. Sci. J. 57, 415-427, https://doi.org/10.1079/WPS20010030

Sklan D., Noy Y., 2003. Crude protein and essential amino acid requirements in chicks during the first week posthatch. Br. Poult. Sci. 44, 266-274, https://doi.org/10.1080/0007166031000124586 
Sklan D., Noy Y., Hoyzman A., Rozenboim I., 2000. Decreasing weight loss in the hatchery by feeding chicks and poults in hatching trays. J. Appl. Poult. Res. 9, 142-148, https://doi.org/10.1093/ japr/9.2.142

Tabedian S.A., Samie A., Pourreza J., Sadeghi G., 2010. Effect of fasting or posthatch diet's type on chick development. J. Anim. Vet. Adv. 9, 406-413, https://doi.org/10.3923/javaa.2010.406.413

Uni Z., Ferket R.P., 2004. Methods for early nutrition and their potential. Worlds Poult. Sci. J. 60, 101-111, https://doi.org/10.1079/ WPS20040009

Wang J.X., Peng K.M., 2008. Developmental morphology of the small intestine of African ostrich chicks. Poult. Sci. 87, 2629-2635, https://doi.org/10.3382/ps.2008-00163
Xu Z.R., Hu C.H., Xia M.S., Zhan X.A., Wang M.Q., 2003. Effects of dietary fructooligosaccharide on digestive enzyme activities, intestinal microflora and morphology of male broilers. Poult. Sci. 82, 1030-1036, https://doi.org/10.1093/ps/82.6.1030

Yang H., Wang Z., Shi S., Lu J., Li W., 2009. Effects of starter feeding time on body growth and viscera development of newly hatched chicks. Ital. J. Anim. Sci. 8, 585-593, https://doi.org/10.4081/ ijas.2009.585

Yegani M., Korver D.R., 2008. Factors affecting intestinal health in poultry. Poult. Sci. 87, 2052-2063, https://doi.org/10.3382/ ps.2008-00091

Zanaty G.A., 2006. Optimum dietary protein and energy levels for Norfa hens during the laying period. Egypt. Poult. Sci. J. 26, 207-220 